\title{
Municipal Methodical Service as a Subject of the University Threefold Network
}

\author{
Elena N. Belova* and Olesya S. Bondareva \\ Krasnoyarsk State Pedagogical University named after V.P. Astafiev \\ 89 Ada Lebedeva Str., Krasnoyarsk, 660060, Russia
}

Received 10.04.2015, received in revised form 22.05.2015, accepted 30.05.2015

\begin{abstract}
The article discusses the possibilities of a municipal methodical service as a subject of a threefold network of self-training organization of additional professional education of a university in order to develop professional competencies of managers and pedagogical workers of a municipal education system. Basic research methods include a concept and system analysis, modelling, monitoring and peer review of representative statements of researchers, modern managers and specialists in the sphere of additional professional training and methodological support for professional development of educators. The authors distinguish and characterize features of the model of the municipal methodical service as a subject of the network organization of additional professional education of the university. The article describes a model of a threefold network of the network self-training organization of additional professional education of a higher school and a model of the municipal methodical service.
\end{abstract}

Keywords: municipal methodical service, triple network, additional professional education of university, network self-training organization.

DOI: 10.17516/1997-1370-2015-8-8-1524-1533.

Research area: pedagogy.

Modern challenges to the education system set new requirements for the organization of activities of additional professional education of a higher school [14, 23] and a municipal methodical service $[8,13,18,24]$ aimed at the effective development of professional, social and personal, managerial competence of managers and staff of educational institutions that enhance the quality of education and competitiveness of the Russian education system.

One of the factors of the development of competencies of managers and employees of the municipal methodical service is networking cooperation of this service and a higher school by transforming the municipal methodical service into a subject of the triple network of self-training organization of additional professional education of Pedagogical University.

Currently, there is a sufficient number of innovative conceptual models of municipal methodical services that are a generalized an "ideal" model, but at the same time, they do not take into account the characteristics of the real municipality and the specific conditions, under which the municipal methodical service (MMS) will be an effective control mechanism of the

(C) Siberian Federal University. All rights reserved

* Corresponding author E-mail address: belovaen@list.ru 
development of the intellectual capital of the education system of the area [17, 19, $24-28]$. The mission of municipal methodological centres under the new conditions becomes building of an educational, resource and methodological network for the continuous professional development of educators in solving actual problems or problems common in teaching.

Our analysis of the problem of the activity of the Municipal budgetary institution "City Information and Methodical Centre" of Borodino of the Krasnoyarsk Territory reveals a contradiction between the objective need to improve management of the development of the professional capacity of the education system employees and the current practice of organization of the MMS in the city of Borodino that does not meet contemporary challenges to education.

In accordance with the contradiction we defined a research problem, which is to find the organizational conditions to ensure that the MMS serves as a mechanism of management of development of professional, social and personal, managerial competences of educators in Borodino.

In the development process of additional professional education (APE) of a pedagogical university we formed a new organizational structure that represents a triple network integrating various subjects around the backbone management core that is a structural subdivision of APE of the university [3]. Based on the results of the research and practical experience, we provide a step by step creation of a network organization of APE of the university, which we believe will be more effective for the development of competences of employees of the APE system of a higher school and all subjects of the triple network [1, 3, 4, 29].

These subjects of a triple network are the structural units of the university, educational institutions and organizations, natural and legal persons with common goals in the development of APE and professional, social, personal, managerial competences of managers and employees of organizations, the resources to achieve them and efficient network interactions between them. The purpose of formation of a network self-training organization is not only to increase the competitiveness of the APE system of the university by development of competences of staff, but also to acquire competitive advantages through the possibility to coordinate all the resources within the network and continuous development of the intellectual capital of the subjects.

The triple network model was developed by us in the context of the introduction of a "triple spiral" [12] and is being put into practice as part of the innovative project "Network space of additional education" of the Strategic Development Program of KSPU named after V. P. Astafiev for 2012-2016 [16]. Mechanisms to achieve the goals and objectives of the project "Network space of additional education" is to create a network organization of APE, including different subjects - innovative university departments equipped not only with modern facilities, equipment, highly professional staff, but also operating in the context of the integration of the three components: science , education and production $[2-3$, 15]. I.e. cooperation with program customers, including a variety of educational institutions, education control facilities, teaching services, educators, entrepreneurs and organizations of the real sector of economics.

The triple network of the organization of APE of the university includes several essential components (Fig. 1):

- a central managing and coordinating unit that carries out intermediary and advisory functions and that may be a structural subdivision of the university 


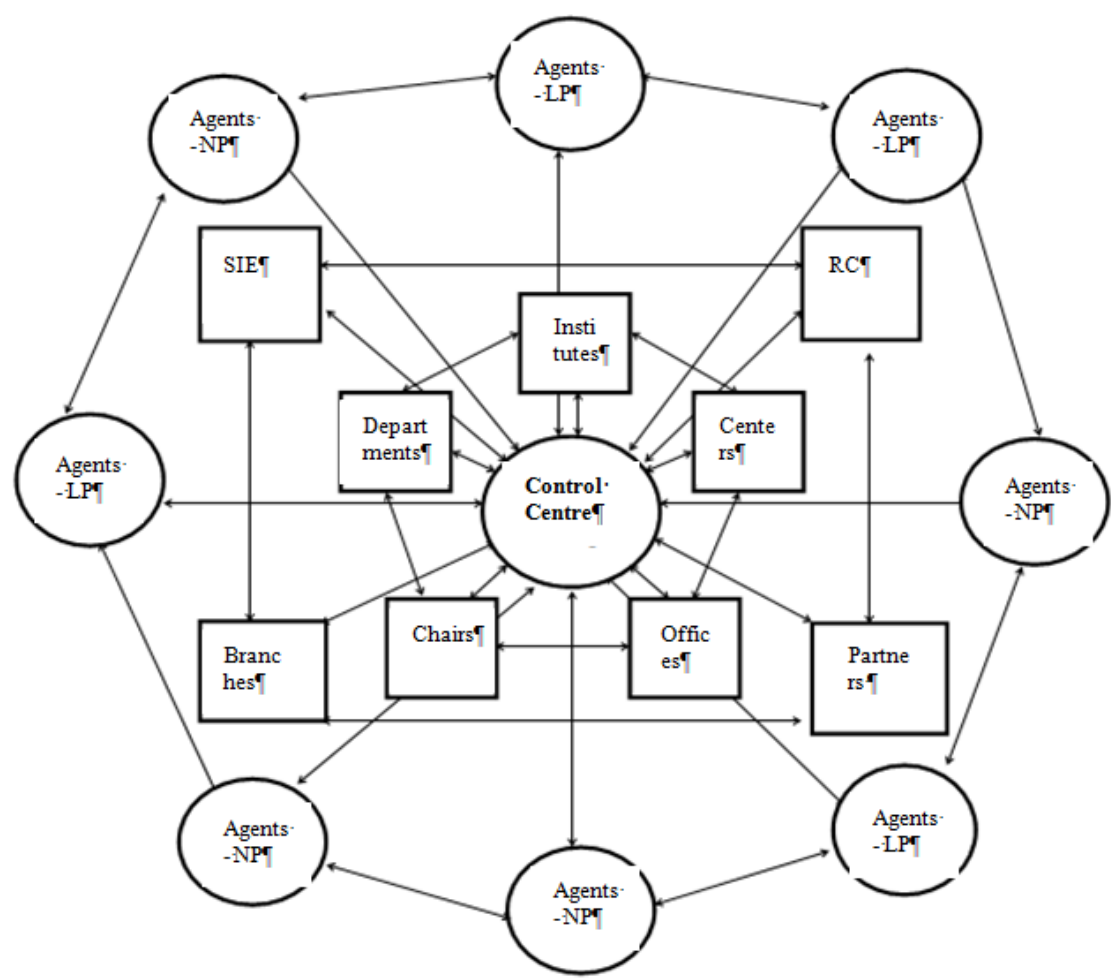

Fig. 1. Model of the triple network of APE of the university

with a positive experience of this type of activity, a range of its regular customers and certain powers. In our university, such a structural subdivision is the Institute of Additional Education and Further Training (IAE\&FT). IAE\&FT is associated with different subjects of the triple network, each of which focuses on specific functions and are interconnected with each other;

- the first circle of the network, the subjects of which are all the structural subdivisions within the university: chairs, departments, institutes, centres, offices, etc., that develop and implement programs of APE, as well as participate in admission of groups of students and organization of the learning process. At the same time the creation of centres of APE within different departments and institutes of the university will contribute to the development of the network;

- the second circle of the network includes structural subdivisions of the university functioning both within the university and outside it. These may include: resource centres, small innovative enterprises, multi-functional centres of applied qualifications, branches of the university, as well as educational organizations partners, including foreign ones working in the field of APE and other organizations involved in the process of marketing, advertising and implementation of the APE programs;

- the third circle of the network includes actual and potential partners: different legal and natural persons acting as agents to promote programs of APE of the university in the Krasnoyarsk 
Territory, across Russia and abroad. Partners can also be students enrolled in these programs using distance learning technologies who, during the learning process, become participants of the network, research and educational centres uniting them by professional, social and personal interests.

Each subsequent circle of the triple network self-training organization of APE of the university is expanding and includes a growing number of subjects, each of which focuses on specific actions and unique processes based on expansion of the resource base and through the integration of existing resources in each subject, for which educational service becomes a joint product.

An analysis of the scientific and methodological literature and the best practices in the development of municipal methodical services showed that the network model of internal organization of the MMS is one of the most promising ways of its development. The effectiveness of the network model of the MMS is proved in practice through its implementation in a number of regions of the Russian Federation, including Tomsk, Novgorod Regions, Perm, Krasnoyarsk and Stavropol Territories, as well as in many other areas $[5-7,11,20-21,25-26$, 28].

Currently, it is especially relevant to create conditions for self-training of the educational institutions workers [9 - 10, 22]. According to the conceptual model of the MMS in the Krasnoyarsk Territory, a methodical service must be a mechanism of the advance construction of educational, methodical and resource network for the continuous professional development of teachers in solving actual problems or issues specific to the educational work.

The methodological base of this model is the system-activity and competence approaches to the organization of activities of the MMS [1]. The value grounds are: a value of a particular person; a value of the professional community; a value of continuous professional education.

Among the main principles of the organization of the modern municipal methodical services, there are such principles as the principle of the network interaction; continuity; individualization; subjectivity; integrativeness and diversification; variability; transparency and accessibility; compulsion; succession [24].

Among the principles of the formation of a network self-training organization of APE of the university, we highlight the following: satisfaction of the educational needs of the customer; mutual benefit of the network subjects; continuous selftraining aimed at development of the professional, social and personal competence of the personnel of the organization and students of the APE programs; cooperation and coordination on the basis of hierarchy and trust; distribution of duties and responsibilities; comprehensive utilization of network resources; joint strategic planning and goal setting; timely and continuous generating, structuring, the exchange of information and knowledge within the subjects of the network and between them [4].

Based on all the above, the basis for the study is the concept of network self-training organizations of APE of a higher school, and the basic conditions conducive to the formation of the MMS as an effective mechanism for managing the development of the intellectual capital of the educational system of the municipality are:

- participation of the MMS of Borodino in a triple network of the additional professional education of the university as a full subject of activity;

- network organization within the MMS of Borodino based on the main provisions of the conceptual model of MMS of the Krasnoyarsk Territory. 
The analysis of the activities of the MMS in Borodino showed that the methodical service of the city has a rich history and has always sought to comply with the requirements of time and to create certain conditions aimed at the selfdetermination of teachers, the presentation of the experience and solution of problems of teacher practices. At the meetings of the City Council they discussed the approaches to the organization of the educational process in modern conditions, the organization of work with the best educational experience, which found its continuation in the work of methodical associations and creative groups. Teachers exchanged experience through master classes and open lessons. In addition to the traditional forms of work with teachers the work included webinars, retreats, participation in the regional projects, professional and educational games.

However, the current model of the MMS of Borodino did not contribute to solving some of the problems we have identified through the method "A tree of problems", the occurrence of which is associated with contemporary challenges to education:

- lack of experience of methodical work of a number of experts of the MMS;

- lack of networking between the structural units of the MMS;

- absence of a single information and methodical space;

- narrow range of external educational resources;

- absence of a reflexive space at events, etc.

At the same time, a root problem of the MMS of Borodino is the lack of professional competence of educators and the intellectual capital of the educational system of Borodino. Therefore, the main objective of the MMS is defined as the increase in the level of professional competence of employees and the development of the intellectual capital of the educational system of Borodino.

In developing a strategy for achieving the goal we used the main provisions of triple network of APE of the university and the network self-training organization of APE of a higher school; as well as the ideas of the organization of the MMS incorporated in the conceptual model of the MMS of the Krasnoyarsk Territory.

The system networking interaction of Krasnoyarsk State Pedagogical University named after V.P. Astafiev and the MMS of Borodino began in 2012, when the Resource Centre of the University was formed on the base of the Municipal budgetary institution "City Information and Methodological Centre". The Resource Centre helped to organize distance professional development of teachers, as well as to provide training, workshops, group counselling of the participants in the educational process. Establishment of the centre was carried out with the active cooperation of experts of the Pedagogical University, including developers of a triple network of self-training organization of additional professional education of the University $[16,27]$.

In the municipality since the early days the Resource Centre has been considered as an effective resource to ensure a subjective position of the MMS of Borodino in a triple network of additional professional education of the university.

Thus, just for the academic year 2013-2014 using the capabilities of the Resource Centre the following has been accomplished:

- distance learning for four heads of educational institutions on the program of professional retraining "Management in Education";

- more than ten distance seminars and lectures for various categories of educators; 
- active work in the network research community "School for a young researcher" - eight children and adult research projects in six disciplines were implemented; participation in two Internet conferences;

- a number of activities for students in the city schools, including the "Mega lesson" held together with the Achinsk students.

The research of the MMS activities in Borodino revealed major inconsistencies with the principles of organization of methodical work: network interaction, individualization, subjectivity, openness and accessibility. In order to eliminate these inconsistencies, we have decided to improve the existing model of the MMS and convert it into a full-fledged subject of the triple network of APE of the university, to activate network interaction aimed at the improvement of the level of competence of employees with a professional position of a "Resource specialist" and to increase the level of motivation of teachers and administrators to professional development. The Model of the MMS of Borodino is presented in Figure 2.

The partners of the MMS are the Krasnoyarsk Regional Institute of Teacher Professional Development (ITPD) and Krasnoyarsk State Pedagogical University named after V.P. Astafiev (KSPU).

The structure of the MMS in Borodino includes:

- City Information-Methodical Centre (CIMC);

- City Methodological Council (CMC);

- Scientific and educational platform of Moscow State Pedagogical University (MSPU) for the development and testing of technology of the individual style of educational activity (ISEA);

- 19 city professional associations represented by the subject city methodological associations (CMA),

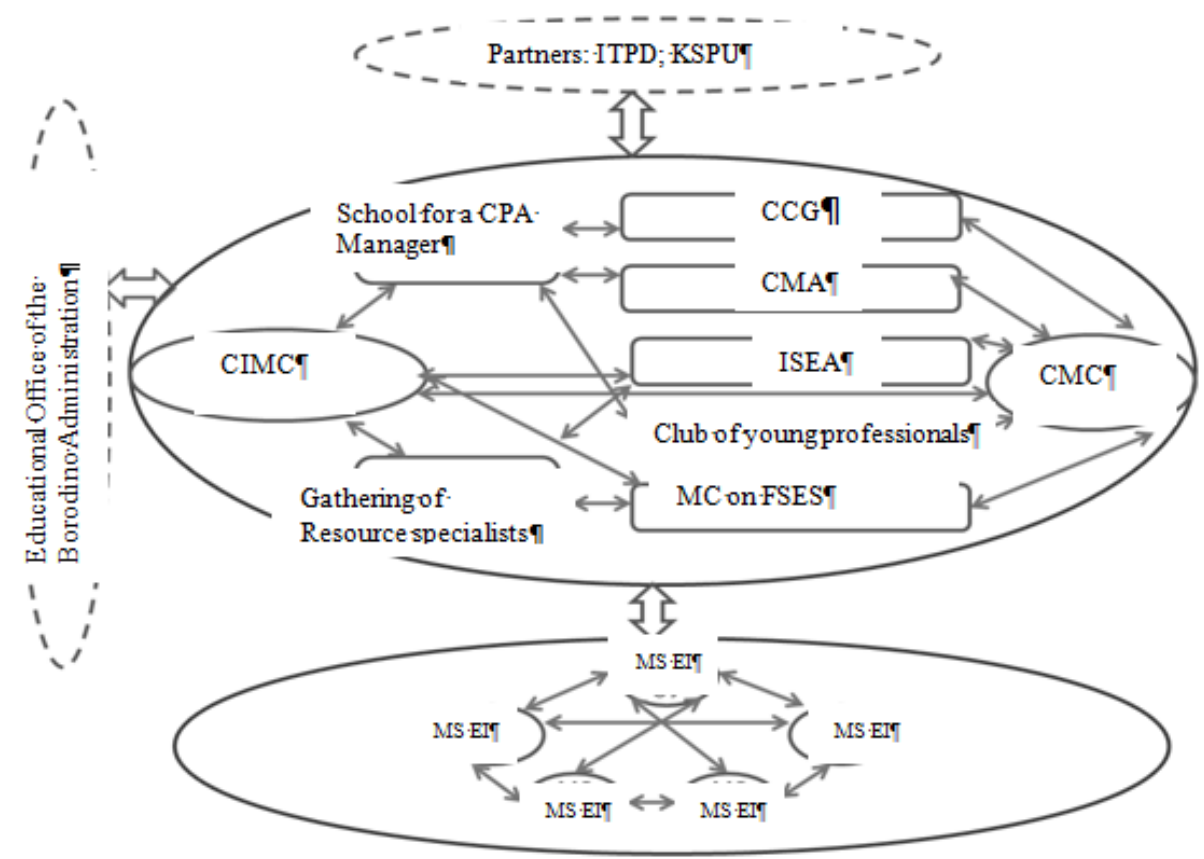

Fig. 2. Model of the MMS in Borodino 
city creative groups $(\mathrm{CCG})$ and a club of young professionals;

- methodological services of educational institutions (MS EI).

All these elements are currently operating in the model of the MMS, while the status of methodological services of educational institutions changed a little, they became fullfledged subjects of the MMS activity with all the attendant rights and responsibilities.

In addition, new specially organized places for interaction and professional development of leaders of the city professional associations (CPA) (permanent seminar "School for a CPA Manager") and employees with a professional position of a "Resource specialist" (gathering of the Resource specialists).

The principal changes are incorporated in the organization of the activities within the MMS that are based on the main principles of organization of the MMS of Borodino, which in turn are based on the principles of the regional MMS and network self-training organization of the university, the subject of which became the MMS in Borodino.

As seen in Figure 2, the network interaction in the model of the MMS in Borodino is carried out both horizontally (between educational institutions, between structural units of the MMS of the municipal level) and vertically (between structural units of the municipal level and the level of educational institutions).

This interaction should also be facilitated by the creation of a unified information educational space (UIES). The effective usage of the opportunities of the UIES will provide implementation of the principles of individualization, subjectivity, openness and accessibility. In order to implement the principles of individualization and subjectivity, it is important to create a reflexive space based on methodological activities that allows identifying of successful experience and practice problems of teachers and motivates them to the creative activity, self-education, self-organization and self-determination.

Thus, effective organizational conditions for the MMS that ensure the development of professional, social and personal, managerial competence of employees of the education system of Borodino is the modernization of this service in order to transform it into a subject of a triple university network.

The first results of the modernization of the MMS activity in Borodino and its transformation into the subject of the triple network of self-training organization of APE of the university allow us to make the following conclusions:

- the process of establishing the MMS as an effective management mechanism for the development of professional competence of managers and teaching staff of the municipal education system of the city is being carried out successfully;

- the tested conditions to improve organization of activity of the MMS in Borodino, namely the participation of the MMS in a triple network of additional professional education of the university as a full-fledged subject of activity and network organization within the MMS on the basis of the main provisions of the conceptual model of the MMS of the Krasnoyarsk Territory contribute to the necessary results.

\section{References}

1. Adolf V. Stepanova, I. (2008). Designing educational process on the basis of competence approach. Higher education in Russia (3). 
2. Belova E.N. (2012). Factors and stages of development of innovative activity in modern educational institution. Belova E.N., Gurtovenko G.A., Butenko, S., Yakovleva N.F. Managing the development of innovative activity in modern educational institution: collective monograph / Krasnoyarsk State Pedagogical University named after V.P. Astafiev. Krasnoyarsk, 7 - 48.

3. Belova E.N. (2013). Triple network as a form of additional professional education of the university. Innovations in continuing education, $(6-7), 82-87$.

4. Belova E.N. (2014). The principles of formation of the network self-training organization at university. Bulletin of KSPU named after V.P. Astafyev, 2 (28), 41 - 47.

5. Bugrova N.S. (2009). Networking in the training of teaching staff. PhD thesis. N.S. Bugrova.

6. Castells, M. (2000). The Information Age, M. (1), 129-200.

7. Davydova, N. (2009). Organization of networking innovation-active educational institutions. Bulletin of Chelyabinsk State Pedagogical University, (12).

8. Dezhina, I., Kiseleva, V. (2007). "Triple spiral" in the innovation system in Russia. Issues of the economics, (12), 06-21.

9. Glagoleva S. A. (2010). Network model of the organization of methodical work in the education system. Methodologist, (9), $28-32$.

10. Grigorenko, E. (2007). Portfolio in a higher school: guidelines for the creation and use. Tomsk: Tomsk State University REC “Institute for Innovation in Education” Institute of Distance Education.

11. Grushevskiy, S. (2015). Express technology of teachers' training to create educational materials on the basis of models and software resources of innovative computer didactics.

12. Kirko V.I., Beloshapkin V.V., Belova E.N. (2013 6). Innovative development of Krasnoyarsk region territories on the basis of the Service Centres net of KSPU named after V.P. Astafiev is a possibility for the "Triple spiral" business-model by G. Etzkowitz Realization. Journal of Siberian Federal University. Humanities \& Social Sciences (10), 1507 - 1513.

13. Kirko V.I., Belova E.N., Beloshapkin V.V. (2013). A network of resource centres of KSPU named after V.P. Astafiev and small enterprises based on them - perspective structure of innovative development of territories. Innovations in Lifelong Learning (6 - 7), 7 - 12.

14. Kiseleva R.A., Kuznetsova O.I., Barteva S.A., Vlasova N.P., Pinegina S.V. (2010). Methodical service center with a network organization as an innovative model of development of municipal methodical service. Methodist (6), $21-32$.

15. Kobzeva, L. (2011). The Entrepreneurial University: how to integrate the university into the economy in the new decade. URL: http:// www.innclub.info/wp-content/uploads/.../Kobzeva

16. Krasilnikova, V.A. (2006). Information and communication technologies in education: tutorial. M: "House of pedagogy".

17. Lunev, A.N., Pugacheva, N.B., Stukolova, L.Z. (2014). Forms of integration of the subjects of the regional market of professional educational services. Concept (1).

18. Makoveeva, V.V. (2012). Networking, a key factor in the development of integration of education, science and business. Bulletin of Tomsk State University, (354).

19. Matvienko, T.N., Matvienko, E.A. (2015). Management of self-education of a teacher in the transition to the new professional standards. Theoretical and applied aspects of modern science, 98 . 
20. Mosicheva, I., Shestak, V., Sigov, A., Berzin, A. Pankov, W., Kurenkov, V. (2008). Network approach to professional development of teaching staff. Higher Education in Russia (1).

21. Municipal methodical service. (2012). Group of authors under the direction of Katyshchuk S.M. Krasnoyarsk. URL: http://uo-kansk.ru/UserFiles/news/files/model (dated 10.06.2014).

22. Pak N.I. (2011). On the concept of informational approach in training. Bulletin of KSPU named after V.P. Astafiev. (1), 91-98.

23. Popova I.N. (2012). Creating a model of networking at the municipal level as a factor in improving the professionalism of teachers of educational institutions. Methodologist (8), $33-40$.

24. Savolainen G.S. (2014). Network Research and Education Centre "Master of the new school" as the environment of the professional development of a teacher. Psychology of learning, (4), 91-100. URL: http://elibrary.ru/item.asp?Id=21325298

25. Sergeeva, O.I. (2015). Methodical preparation of future teachers as one of the conditions of their skills. Bulletin of the Judiciary, 130.

26. Tretiak, O.A., Rumiantseva, M.N. (2003). Network forms of inter-firm cooperation: approaches to the explanation of the phenomenon. Russian Management Journal, 1 (2), 25-50.

27. Vasilevskia E.V. (2004). Development of the network organization of municipal methodical service: Candidate of Pedagogical Sciences: 13.00. 08. Moscow.

28. Vladyka M.V. (2010). Development and implementation of the innovative potential of the university. Thesis for the degree of Doctor of Economics, Belgorod, 22.

29. Zubareva, T.A. (2011). Use of networking for innovative development of educational institutions. Ph.D. thesis, 13 (01). 


\title{
Муниципальная методическая служба
}

\section{как субъект тройной сети университета}

\author{
Е.Н. Белова, О.С. Бондарева \\ Красноярский государственный педагогический университет \\ им. В.П. Астафьева \\ Россия 660060, Красноярск, ул. Ады Лебедевой, 89
}

\begin{abstract}
Рассматриваются возможности мунииипальной методической службы как субъекта тройной сети самообучающейся организачии дополнительного профессионального образования университета с иелью развития профессиональных компетентностей руководителей и педагогических работников муниципальной системы образования. Основные методы исследования - концептуальный и системный анализ, моделирование, наблюдение и экспертная оценка репрезентативных высказываний исследователей, современных руководителей и специалистов в сфере дополнительного профессионального образования и методического сопровождения повышения квалификачии работников системы образования. Авторы статьи выделяют и характеризуют особенности модели мунииипальной методической службы как субъекта сетевой организации дополнительного профессионального образования университета. Описаны модель тройной сети сетевой самообучающейся организачии дополнительного профессионального образования высшей иколь и модель муниципальной методической службы.
\end{abstract}

Ключевые слова: муниципальная методическая служба, тройная сеть, дополнительное профессиональное образование университета, сетевая самообучающаяся организация.

Научная специальность: 13.00.00 - педагогические науки. 